\title{
Aplikasi Mindahan New Normal Sebagai Panduan Adaptasi Kebiasaan Baru
}

\author{
Abdur Rouf ${ }^{1}$, Rina Yulianti2* \\ ${ }^{1}$ Program Studi Sistem Informasi Fakultas Teknik Universitas Trunojoyo Madura \\ ${ }^{2}$ Program Studi Ilmu Hukum Fakultas Hukum Universitas Trunojoyo Madura \\ Jl. Raya Telang No 02 Kamal Bangkalan 69162 Madura Jawa Timur \\ *E-mail : rinayulianti@trunojoyo.ac.id \\ DOI: https://doi.org/10.21107/pangabdhi.v7i1.9348 \\ Naskah diterima 1 Maret 2021, Revisi 20 Maret 2021, Terbit 29 April 2021
}

\begin{abstract}
The world began to be attacked by a new outbreak of Covid-19 that can infect people quickly, infect the respiratory tract and cause fatalities. To learn and improve knowledge about Covid-19 can be done through mobile devices. This research aims to create an application as a new normal guide to encounter the Covid19 pandemic for the community, especially Mindahan Village. This application was developed with java programming language by utilizing android studio. The results of this study are Mindahan New Normal application based on android as a new normal guide with self-check feature, Covid-19 response webview, and emergency service contactsKey Words : automatic disinfectant booth, Covid-19, droplet, contagion, infected, viruses.
\end{abstract}

Keywords : new normal, application, Covid-19, Mindahan village

\section{PENDAHULUAN}

Semenjak Desember akhir 2019, dunia mulai diserang wabah baru yang dapat menjangkiti masyarakat dengan cepat menginfeksi saluran pernapasan dan memunculkan korban jiwa yaitu Severe Acute Respiratory Syndrome Coronavirus2 (SARS-CoV-2) atau disebut juga Coronavirus Disease 2019 (Covid-19). Ada sekitar 200-an negara di dunia yang telah terjangkit virus Covid19 (Ilpaj dan Nurwati, 2020). Gejala ringan Covid-19 adalah demam, batuk, tenggorokan kering, dan sesak napas (Rahmawati dan Purwanto, 2020).

Guna mempelajari dan meningkatkan pengetahuan tentang Covid-19 dapat dilakukan melalui perangkat mobile (Rihyanti dan Yanti, 2020). Aplikasi pantau Covid-19 dapat memberi kemudahan akses informasi tentang penyebaran Covid-19, upaya pencegahan, dan diagnosa awal (Thohari dan Vernandez, 2020). Tampilan aplikasi mobile dapat menunjukan informasi mengenai contact emergency call Covid-19, dan informasi tentang pencegahan penularannya ( $\mathrm{Al}$ Isfahani et al., 2020). Selain itu, aplikasi dapat juga mengimplementasikan rule based deteksi dini untuk memberikan solusi dalam pencegahan Covid-19 sejak awal (Etikasari et al., 2020).

Kaitannya dengan pencegahan Covid-19, aplikasi sistem pakar dapat berguna untuk pengambilan keputusan yang dapat membantu tenaga medis melakukan tindakan sebelum tes memastikan bahwa pasien positif atau negatif Covid-19 (Suryana et al., 2020). Sistem pakar Covid-19 dapat mengatasi adanya ketidakpastian dalam pengambilan keputusan hasil periksa kesehatan berdasarkan gejala-gejala yang dirasakan (Fatkhurozi \& Kurniawan, 2020). Aplikasi android untuk mendiagnosis penyakit Covid-19 membantu masyarakat dalam melakukan diagnosa pencegahan penularan Covid-19 dan memberikan respons positif kepada masyarakat terkait pencegahan Covid-19 (Al Hakim, 2020).

Desa Mindahan adalah salah satu desa yang ada di Kecamatan Batealit, Jepara, Provinsi Jawa Tengah yang sampai saat ini memiliki catatan kasus positif Covid-19 sejumlah 20 orang dengan rincian sebanyak 1 isolasi, 17 sembuh, dan 2 meninggal (22/10). Meski tidak seberapa besar tetapi tetap saja dampak yang dirasakan akibat wabah ini sangat luar biasa, maka dari itu sikap masyarakat harus lebih berhati-hati dan mengikuti anjuran pemerintah sangat diperlukan seperti menerapkan physical distancing, selalu mencuci tangan dan menggunakan masker ketika keluar rumah. Hal ini berguna untuk menumbuhkan 
keyakinan masyarakat dalam kegiatan adaptasi kebiasaan baru (new normal).

Kegiatan pengabdian masyarakat ini bertujuan untuk menciptakan sebuah aplikasi sebagai panduan adaptasi kebiasaan baru dalam menghadapi pandemi Covid-19 bagi masyarakat Desa Mindahan. Berdasarkan deskripsi di atas, peneliti membuat Aplikasi "Mindahan New Normal" untuk masyarakat Desa Mindahan yang membantu dalam upaya melaksanakan adaptasi kebiasaan baru (new normal) di tengah pandemi Covid-19. Pada aplikasi akan terdapat berbagai macam informasi mengenai Adaptasi Kebiasaan Baru yang mudah dipahami untuk masyarakat di Desa Mindahan.

\section{METODE}

Kegiatan pengabdian masyarakat ini berjalan dalam rentang waktu 31 Oktober 2020 hingga 26 Desember 2020 dengan sasaran warga Desa Mindahan, Kabupaten Jepara, Provinsi Jawa Tengah. Penelitian ini menggunakan konsep Research and Development, yaitu metode untuk menghasilkan suatu produk tertentu dan mengkaji kefektifan produk tersebut (Pujianto, 2020). Aplikasi dikembangkan dengan bahasa pemrograman java dengan memanfaatkan android studio. Pembuatan aplikasi dilakukan melalui tahapan analisis fitur, perancangan aplikasi, pengkodean, dan pengujian blackbox.

Analisis fitur kebutuhan fungsional akan berisi perincian daftar fitur-fitur aplikasi yang dibutuhkan dan akan diprogram. Pada proses ini akan dilakukan penggambaran alur penggunaan aplikasi yang berkaitan dengan proses yang akan berjalan dalam sistem nantinya. Aplikasi Mindahan New Normal berbasis android ini akan memiliki beberapa fitur, antara lain:

a. Beranda: Menampilkan beberapa fitur-fitur utama dalam aplikasi.

b. Periksa: Memfasilitasi pengguna untuk melakukan periksa mandiri terhadap kemungkinan positif COVID-19.

c. Tips: Menampilkan informasi berupa prosedur adaptasi kebiasaan baru dan tips kesehatan mencegah penularan COVID-19.

d. FAQ: Menampilkan pertanyaan yang sering ditanyakan masyarakat seputar COVID-19.

e. Web Tanggap Covid: berupa pilihan web tanggap Covid yang dapat diakses dari aplikasi baik dari web tanggap Covid Kabupaten Jepara, Provinsi Jawa Tengah dan/ Web Tanggap Covid Nasional. f. Pesan \& Panggilan Kegawatdaruratan: berupa tombol untuk melakukan pengiriman pesan kegawatdaruratan Covid-19 (melalui wa) atau untuk melakukan panggilan secara langsung kepada tim satgas Covid-19.

g. Share App: berupa tombol untuk membagikan link download aplikasi dan/ berisi pesan ajakan untuk menggunakan aplikasi.

h. Tentang aplikasi: berisi informasi mengenai pembuat aplikasi dan info fungsionalitas aplikasi.

Analisis kebutuhan non fungsional dalam pembuatan Aplikasi Mindahan New Normal akan berguna untuk persiapan alat dan spesifikasi kebutuhan perangkat yang mendukung pembuatan aplikasi. Spesifikasi kebutuhan non fungsional ini akan dibedakan menjadi analisis untuk perangkat keras (hardware), analisis untuk perangkat lunak (software), dan analisis kebutuhan lainnya. Kebutuhan-kebutuhan non fungsional perangkat Aplikasi Mindahan New Normal yaitu:

a. Perangkat Keras (Hardware)

Perangkat keras yang digunakan dalam penelitian ini memiliki spesifikasi sebagai berikut:

Tabel 1. Spesifikasi Hardware

\begin{tabular}{lll}
\hline No & Kategori Hardware & Spesifikasi \\
\hline 1 & Manufacturer $(\mathrm{PC})$ & Lenovo \\
2 & Model & Ideapad 320 \\
3 & Processor & AMD A9-9420 APU \\
& & 7TH GEN \\
4 & Memory (RAM) & DDR4 4GB \\
5 & Graphic Card & AMD RADEON 530 \\
6 & Hard Disk & 1 TB \\
\hline
\end{tabular}

\section{b. Perangkat Lunak}

Perangkat lunak yang digunakan dalam pembuatan aplikasi adalah sebagai berikut:

Tabel 2. Spesifikasi Software

\begin{tabular}{llll}
\hline No & Kategori Software & Spesifikasi & \\
\hline 1 & $\begin{array}{l}\text { Operating System } \\
\text { (OS) }\end{array}$ & Windows 10 Pro (64 \\
& bit) & \\
2 & Pemrograman & Java & \\
3 & Editor & Android $\quad$ Studio, \\
& & Notepad++ & \\
4 & Browser & Google Chrome \\
5 & Diagram Editor & Ms. Visio 2013 \\
\hline
\end{tabular}

Untuk perancangan aplikasi ini dibuatkan usecase diagram untuk menggambarkan keterhubungan antara pengguna (user) dengan sistem. Skema sistem yang dibuat tergambarkan pada Gambar 1. 


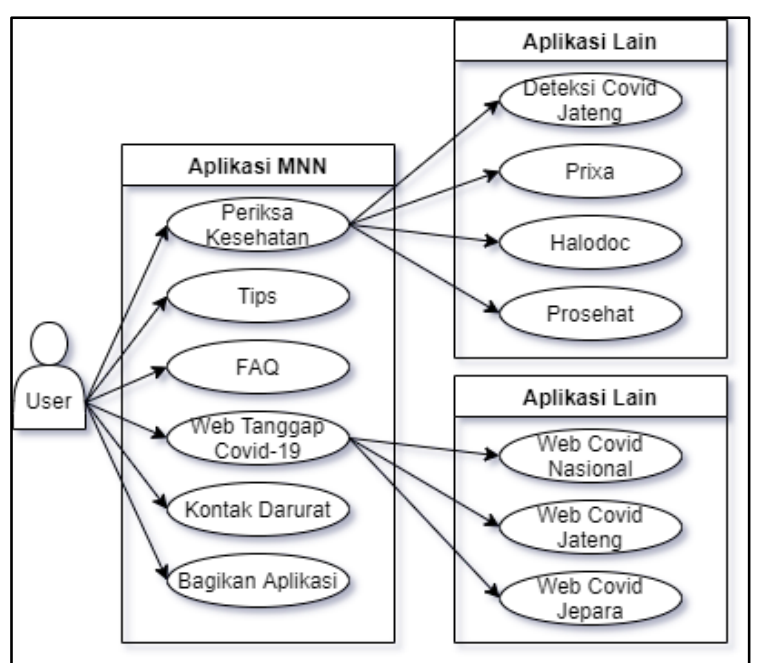

Gambar 1. Usecase Diagram Aplikasi

Pengguna aplikasi dapat mengakses fitur-fitur pada aplikasi "Mindahan New Normal" dan beberapa fitur tersebut juga terhubung ke beberapa fitur pada aplikasi lain. Tampilan antarmuka aplikasi digambarkan pada Gambar 2. Rancangan tersebut adalah untuk memperlihatkan tampilan beranda pada aplikasi yang akan dibuat. Beberapa fitur utama aplikasi disatukan pada satu tampilan antarmuka.

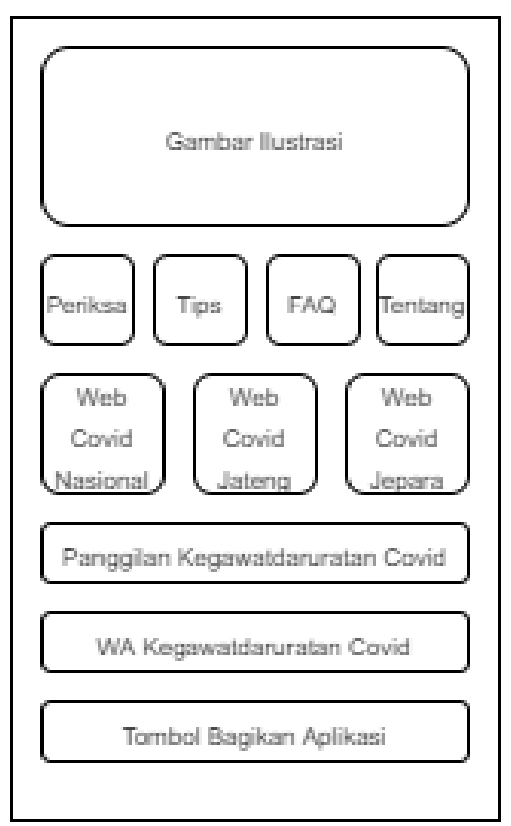

Gambar 2. Rancangan Tampilan Antarmuka Beranda Aplikasi

Setelah perancangan dibuat, dilanjutkan ke proses pengkodean. Rancangan aplikasi mulai diprogram dan diimplementasikan dengan bahasa pemrograman. Proses ini dapat dilihat pada Gambar 3. Pada tahap pengkodean aplikasi dibuatkan layout (tata letak) tampilan antarmuka sistem dan penyiapan callback data sistem yang akan ditampilkan, melalui class activity pada pemrograman Java.

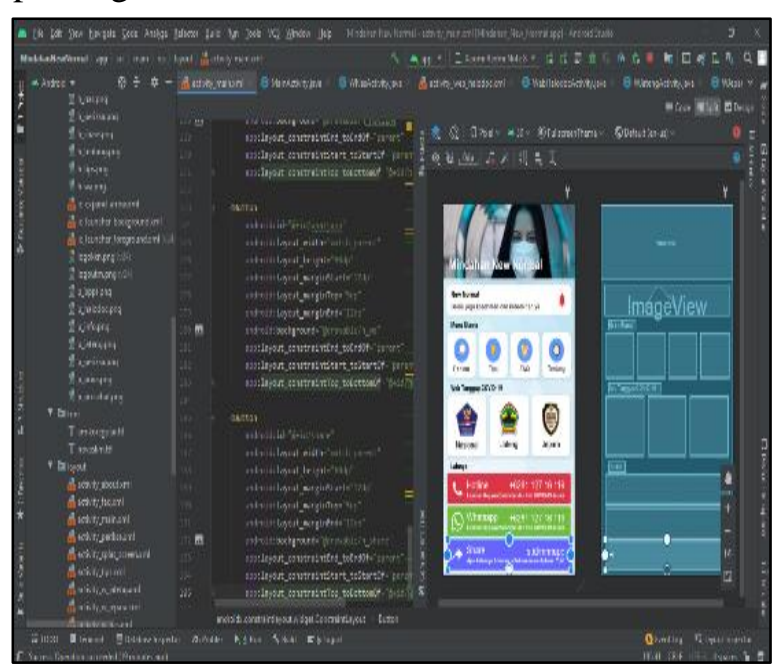

Gambar 3. Pembuatan Program

\section{HASIL DAN PEMBAHASAN}

Hasil dari implementasi program terlihat dari beberapa gambar berikut. Pada tampilan beranda aplikasi, tata letak tombol menu dibuat berdasarkan kelompok kategorinya masingmasing, yaitu menu utama, web tanggap Covid19, dan menu lainnya. Menu utama terdiri dari periksa, tips, faq, dan tentang aplikasi. Menu web tanggap Covid terdiri dari web Covid nasional, Jawa Tengah, dan Jepara. Dan untuk menu lainnya terdiri dari panggilan kegawatdaruratan Covid, WhatsApp kegawatdaruratan Covid, dan tombol bagikan aplikasi (Gambar 4).

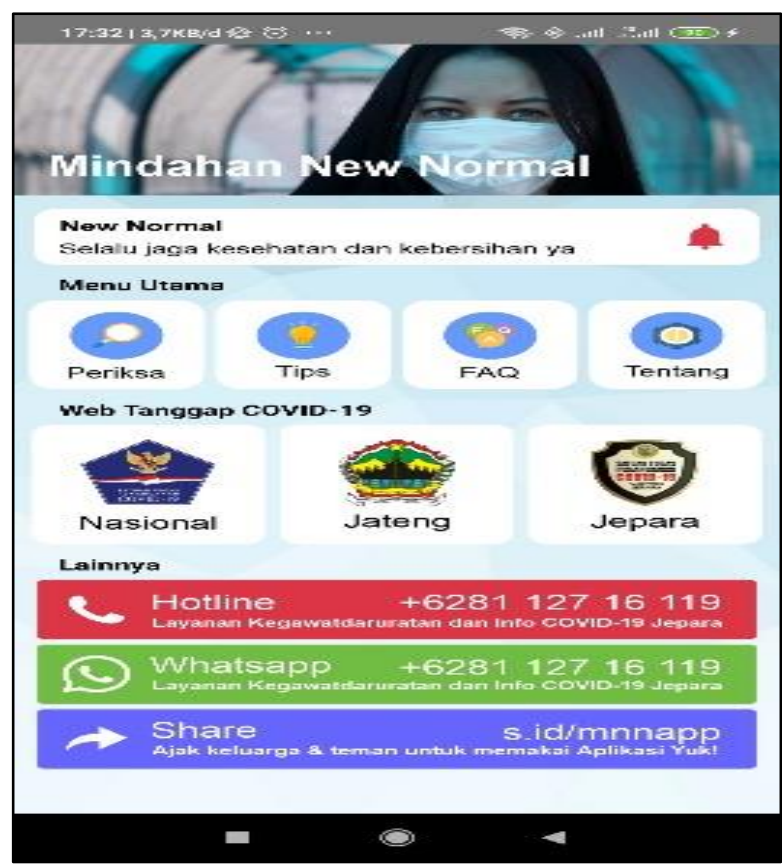

Gambar 4. Tampilan Beranda 


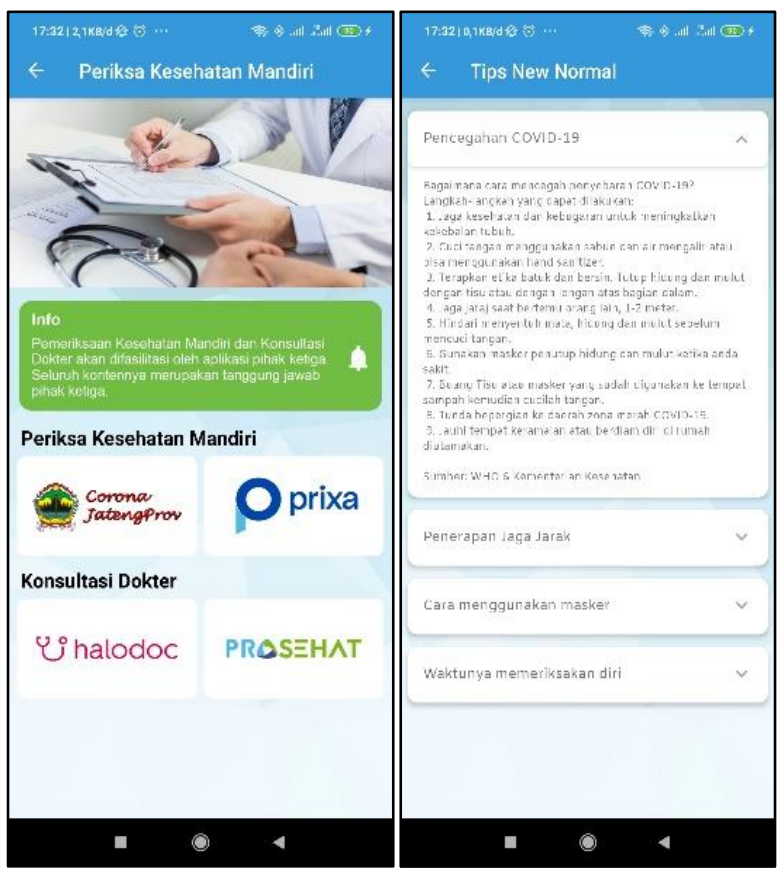

Gambar 5. Tampilan Menu Periksa dan Tips

Pada tampilan menu periksa (Gambar 5) ada beberapa pilihan menu yaitu deteksi dini Covid jawa tengah, prixa, konsultasi di halodoc, dan konsultasi di prosehat. Menu tips (Gambar 6) memberikan beberapa informasi tentang tips kesehatan pencegahan Covid-19.
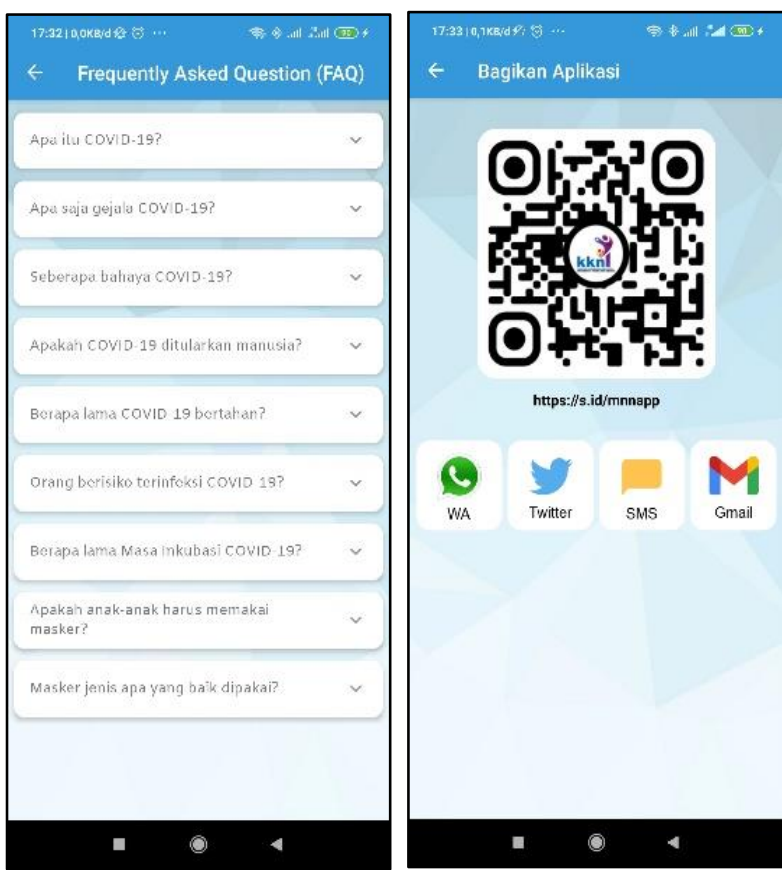

Gambar 6. Menu FAQ dan Bagikan Aplikasi

Selanjutnya pada menu Frequently Asked Question (Gambar 6) memberikan informasi tentang pertanyaan yang sering diajukan seputar Covid-19 disertai jawabannya. Pada aplikasi juga menyediakan fitur berbagi aplikasi (Gambar 6) untuk mengajak orang lain di sekitar pengguna untuk ikut menginstalasi dan menggunakan aplikasi. Pengguna aplikasi dapat berbagi melalui link url, qrcode, whatsapp, twitter, dan gmail. Kemudian aplikasi "Mindahan New Normal" yang telah selesai dibuat dilakukan pengujiannya dengan metode blackbox. Hasil pengujian ditampilkan pada tabel berikut.

Tabel 3. Hasil Pengujian Aplikasi

\begin{tabular}{|c|c|c|c|}
\hline No & Skenario & Hasil & Ket \\
\hline 1 & Menu Periksa & $\begin{array}{l}\text { Menampilkan } \\
\text { pilihan periksa } \\
\text { kesehatan mandiri } \\
\text { dan konsultasi } \\
\text { dokter }\end{array}$ & Valid \\
\hline 2 & Menu Tips & $\begin{array}{l}\text { Menampilkan } \\
\text { informasi tips } \\
\text { kesehatan } \\
\text { pencegahan } \\
\text { Covid-19 }\end{array}$ & Valid \\
\hline 3 & Menu FAQ & $\begin{array}{l}\text { Menampilkan } \\
\text { pertanyaan dan } \\
\text { jawaban seputar } \\
\text { Covid-19 }\end{array}$ & Valid \\
\hline 4 & $\begin{array}{l}\text { Menu Web } \\
\text { Tanggap Covid }\end{array}$ & $\begin{array}{l}\text { Menampilkan } \\
\text { tampilan web } \\
\text { yang dipilih }\end{array}$ & Valid \\
\hline 5 & $\begin{array}{l}\text { Menu Pesan \& } \\
\text { Panggilan } \\
\text { Kegawatdaruratan }\end{array}$ & $\begin{array}{l}\text { Dapat melakukan } \\
\text { panggilan telepon } \\
\text { atau mengirim } \\
\text { pesan } \\
\text { kegawatdaruratan } \\
\text { melalui whatsapp }\end{array}$ & Valid \\
\hline 6 & $\begin{array}{l}\text { Menu Berbagi } \\
\text { Aplikasi }\end{array}$ & $\begin{array}{l}\text { Dapat berbagi } \\
\text { aplikasi sesuai } \\
\text { cara yang dipilih }\end{array}$ & Valid \\
\hline
\end{tabular}

\section{KESIMPULAN}

Hasil kegiatan pengabdian kepada masyarakat berupa aplikasi Mindahan New Normal berbasis android sebagai panduan adaptasi kebiasaan baru dengan dilengkapi fitur periksa mandiri, webview tanggap Covid-19, dan kontak layanan kegawatdaruratan. Dalam fitur periksa mandiri terdapat proses pemeriksaan mandiri dan konsultasi dokter. Di fitur webview tanggap Covid-19 terdiri dari website tanggap Covid-19 nasional, Jawa Tengah dan Jepara. Dan untuk fitur kontak layanan kegawatdaruratan terdapat tombol panggilan cepat maupun kirim pesan WhatsApp ke Tim Satgas Covid-19 Jepara. Hasil pengujian dengan metode Block Box memberikan hasil bahwa aplikasi dapat dijalankan sesuai dengan yang diharapkan. Dalam aplikasi Mindahan New Normal juga dilengkapi fitur berbagi aplikasi, dimana aplikasi yang digunakan dapat dibagikan ke orang lain melalui WhatsApp, Twitter, SMS, dan Gmail. Untuk saran 
pengembangan selanjutnya pada aplikasi ini yaitu dapat dikembangkan lagi untuk penambahan fitur-fiturnya seperti infografis Covid-19, info rumah sakit atau puskesmas terdekat, dan lainlain.

\section{UCAPAN TERIMA KASIH}

Penulis mengucapkan terima kasih kepada Satgas Covid-19, masyarakat dan Petinggi Desa Mindahan, Dosen Pembimbing Lapangan dan LPPM Universitas Trunojoyo Madura sebagai mitra pengabdian kepada masyarakat, serta pihakpihak lain yang telah membantu penulis dalam proses penulisan artikel.

\section{DAFTAR PUSTAKA}

Al Hakim, R. R. (2020). Pencegahan Penularan Covid-19 Berbasis Aplikasi Android Sebagai Implementasi Kegiatan KKN Tematik Covid19 di Sokanegara Purwokerto Banyumas. Community Engagement and Emergence Journal (CEEJ). Vol 2 (1). 7-13 pp.

Al Isfahani, F., Nugraha, F., Mubarok, R., \& Rahmatulloh, A. (2020). Implementasi Web Service untuk Aplikasi Pemantau Coronavirus Disease 2019 (COVID-19). Innovation in Research of Informatics (INNOVATICS). Vol $2(1)$.

Etikasari, B., Puspitasari, T. D., Kurniasari, A. A., \& Perdanasari, L. (2020). Sistem Informasi Deteksi Dini Covid-19. Jurnal Teknik Elektro dan Komputer. Vol 9 (2). 101-108 pp.

Fatkhurozi, B., \& Kurniawan, A. A. (2020). Sistem Pakar untuk Diagnosa Penyakit Sars,
Mers, dan Covid-19 Menggunakan Metode Certainty Factor. In SENASTER" Seminar Nasional Riset Teknologi Terapan" (Vol. 1).

Ilpaj, S. M., \& Nurwati, N. (2020). Analisis Pengaruh Tingkat Kematian Akibat Covid-19 Terhadap Kesehatan Mental Masyarakat di Indonesia. Focus: Jurnal Pekerjaan Sosial. Vol 3 (1). 16-28 pp.

Pujianto, P. (2020). Aplikasi Self Assesment Checkup Covid-19 Berbasis Android. Jurnal Digital Teknologi Informasi. Vol 3 (1). 28-34 pp.

Rahmawati, S., \& Purwanto, E. (2020). Inovasi EGelang Sebagai Alat Deteksi Dini Untuk Meminimalisasi Penyebaran Covid-19. Jurnal Informa. Vol 6 (2). 35-39 pp.

Rihyanti, E., \& Yanti, S. N. (2020). Pembuatan Aplikasi Mobile Learning Informasi Pertolongan Pasien Positif Covid-19 Berbasis Android. Journal of Information System, Informatics and Computing. Vol 4 (1). 122$133 \mathrm{pp}$.

Suryana, M. F., Fauziah, F., \& Sari, R. T. K. (2020). Implementasi Sistem Pakar Menggunakan Metode Certainty Factor Untuk Mendiagnosa Dini Corona Virus Desease (COVID-19). Jurnal Media Informatika Budidarma. Vol 4 (3). 559-566 pp.

Thohari, A. N. A., \& Vernandez, A. B. (2020). Aplikasi Monitoring Kasus Coronavirus Berbasis Android. JTET: Jurnal Teknik Elektro Terapan. Vol 9 (1).12-17 pp. 